EESTI NSV TEADUSTE AKADEEMIA TOIMETISED. KEEMIA

ИЗВЕСТИЯ АКАДЕМИИ НАУК ЭСТОНСКОИ ССР. ХИМИЯ

PROCEEDINGS OF THE ACADEMY OF SCIENCES OF THE ESTONIAN SSR. CHEMISTRY

$1984,33,4$

Tiina LINNAS, O. KIRRET

удК 547.239 .1

\title{
THE USE OF ISOCYANIDES FOR THE IMMOBILIZATION OF BIOLOGICAL MOLECULES ON CELLULOSE CARRIERS
}

Tiina LINNAS, O. KIRRET. ISOTSUANIIDIDE KASUTAMINE BIOLOOGILISTE MOLEKULIDE IMMOBILISATSIOONIKS TSELLULOOSIKANDJATEL

ТИйН ЛИННАС, О. КИРРЕТ. ПРИМЕНЕНИЕ ИЗОЦИАНИДОВ ДЛЯ ИММОБИЛИЗАЦИИ БИО ЛОГИЧЕСКИХ МОЛЕКУЛ НА ЦЕЛЛЮЛОЗНЫХ НОСИТЕЛЯХ

Support materials, such as polyacrylamide and dextran derivatives used for enzyme immobilization and affinity chromatography are not ideal for solving some problems at large-scale operation in columns. We have investigated the covalent fixation of biologically active substances to carboxymethylcellulose (CM-cellulose), aminoethylcellulose (AE-cellulose) and 4- $\beta$-oxyethylsulfonyl-2-aminoanizole ether of cellulose (CE).

In this paper we report experiments performed in order to find conditions which permit high coupling efficiency. A model compound, trypsin, has been immobilized on various cellulose carriers. The dependence of the activity of the carrier on the $\mathrm{pH}$ of binding, the binding time and the medium were investigated.

\section{Material and methods}

Enzymes. Bovine trypsin (EC 3.4.4.4) «B» was obtained from the Olaine Works (USSR). Immobilized trypsin was assayed with BAEE (N-benzoyl-L-arginine ethyl ester) at $25^{\circ} \mathrm{C}$ with the $\mathrm{pH}$-stat method.

Chemicals. BAEE. $\mathrm{HCl}$ was obtained from Reanal Co. (Hungary). CMcellulose and AE-cellulose were produced by the Yerevan Chemical Works, and CE was synthesized in our laboratory by the method described in [1]. Cyclohexylisocyanide was synthesized in our laboratory by the method described in $\left[^{2}\right]$.

Binding conditions. Trypsin was dissolved in $7 \mathrm{ml}$ of $0.1 \mathrm{~N} \mathrm{NaCl}$ solution, at $\mathrm{pH} 6.0,1 \mathrm{~g}$ of carrier, $50 \mathrm{ml}$ of acetaldehyde and $125 \mathrm{ml}$ of cyclohexylisonitrile being added. The solution was shaken for $4 \mathrm{~h}$ at room temperature and washed with $0.1 \mathrm{~N} \mathrm{NaCl}$ solution ( $\mathrm{pH} 6.0$ ).

\section{Results and discussion}

We have investigated the covalent fixation of biologically active substances to polymers using the four-component condensation of an isocyanide, a primary amine, a carbonyl compound and a carboxylic group. 


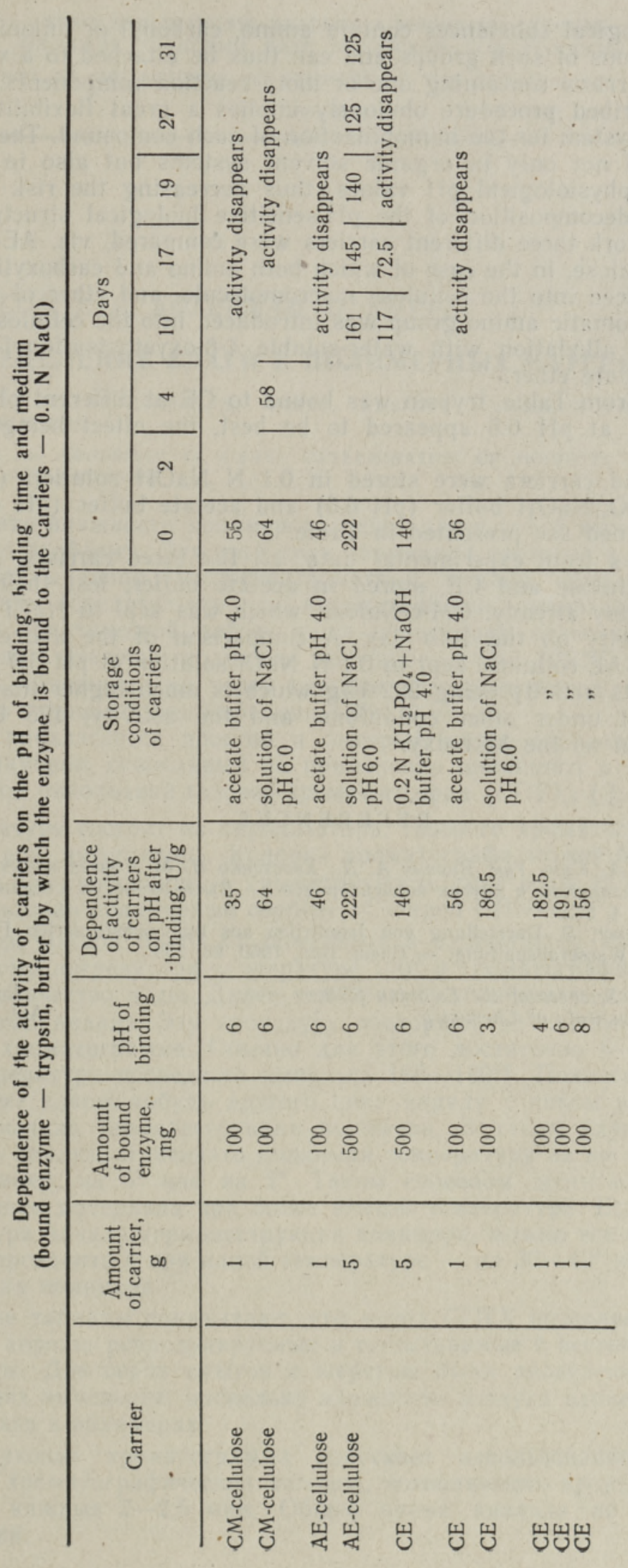


Several biological substances contain amino, carbonyl or anionic groups or combinations of such groups and can thus be attached to a variety of polymeric carriers containing one or more reaction components.

The described procedure obviously implies a great flexibility in the choice of a system for the immobilization of each compound. The reaction may proceed not only in organic solvent systems but also in aqueous solution at physiological $\mathrm{pH}$ values, thus decreasing the risk of denaturation or decomposition of the $\mathrm{pH}$-sensitive biological structures.

In this work three different carriers were compared, viz. AE-cellulose and CM-cellulose, in the case of which both amino and carboxylic groups were introduced into the cellulose macromolecule, and ether of cellulose, where the aromatic amino group was introduced into the cellulose macromolecule by alkylation with water-soluble 4 - $\beta$-oxyethylsulfonyl-2-aminoanizole sulphate ether.

As seen from Table, trypsin was bound to $\mathrm{CE}$ at different $\mathrm{pH}$ values. The binding at $\mathrm{pH} 6.0$ appeared to be best, the effect being highest, $191 \mathrm{U} / \mathrm{g}$.

The bound carriers were stored in $0.1 \mathrm{~N} \mathrm{NaOH}$ solution ( $\mathrm{pH} 4.0$ ), $0.2 \mathrm{M} \mathrm{KH}_{2} \mathrm{PO}_{4} / \mathrm{NaOH}$ buffer $(\mathrm{pH} 6.0)$ and acetate buffer $(\mathrm{pH} 4.0)$. The results obtained are presented in Table.

As follows from experimental data, all the three carriers, AE-cellulose, CM-cellulose and CE, stored in acetate buffer, lost their activity on the 2nd day already. CM-cellulose, which was kept in $\mathrm{NaCl}$ solution, lost its activity on the 10th day. A comparison of the above carriers showed that $\mathrm{AE}$-cellulose kept in $0.1 \mathrm{~N} \mathrm{NaCl}$ solution at $\mathrm{pH} 6.0$ appeared to be best, its activity being $222 \mathrm{U} / \mathrm{g}$ which is much higher than that of carriers kept under other conditions, and the activity, $125 \mathrm{U} / \mathrm{g}$, was retained even on the 31 st day.

\section{REFERENCES}

1. Роговин 3. А., Сунь Тун, Вирник А. Д., Хвостенко Н. М. Синтез новых производных целлюлозы и других полисахаридов. - Высокомолекул. соединения, 1962. IV, № 4, 572

2. Ugi, J., Meyer, R. Darstellung von Isonitrilen aus monosubstituierten Formamiden durch Wasserabspaltung. - Chem. Ber., 1960, 93, 239.

Academy of Sciences of the Estonian SSR, Institute of Chemistry

Received Apr. 23, 1984 